\title{
Satisfaction of Basic Psychological Needs and Autonomous Motivation in School Context: A Test of Additive, Synergistic, and Balance Hypotheses
}

Saulè Raižienè ${ }^{1}$, Ingrida Gabrialavičiūtė', Renata Garckija' and Gintautas Silinskas

'Mykolas Romeris University, Institute of Psychology

${ }^{2}$ University of Jyväskylä, Department of Psychology

\section{Abstract}

The present study examined the influence of the three basic psychological needs on autonomous motivation in educational settings in the light of additive, synergistic, and balance hypotheses. Participants were 679 high school students $\left(M_{\text {age }}=16.16,49.3 \%\right.$ girls). The findings supported the additive hypothesis: all three needs had unique effects on autonomous motivation. The synergistic hypothesis was only partially supported: one two-way interaction between autonomy and competence had effect on autonomous motivation. A high level of satisfaction of the need for autonomy led to autonomous motivation regardless of satisfaction of the need for competence. However, competence was positively related to autonomous motivation only when the need for autonomy was low. The balance hypothesis was also supported: balance in needs satisfaction had a significant effect in addition to additive and synergistic effects.

Key words: educational settings; need for autonomy; need for competence; need for relatedness; self-determination theory.

\section{Introduction}

School is one of the contexts where the developing individual spends a considerable amount of time. Educational context provides access to information, opportunities to socialize, and develop individual strengths. Thus, school success is a gateway to thriving 
in adulthood. Students' active involvement in both academic and social school activities is crucial for taking advantages of opportunities available in educational settings. However, students' enthusiasm for learning deteriorates during school years, especially in periods of transition (Lepper, Corpus, \& Iyengar, 2005; Skinner, Kindermann, Connell, \& Wellborn, 2009). Therefore, especially during the last years of formal schooling, it is important to examine resources of high quality academic motivation.

Over the past decades, self-determination theory (SDT; Deci \& Ryan, 2000) has provided a useful framework in explaining the underlying processes of students' motivation. SDT posits that when students experience satisfaction of innate psychological needs for autonomy, competence and relatedness, they maintain autonomous motivation (i.e., engaging in an activity for the sake of itself, because it is enjoyable or meaningful). Basic psychological needs are defined as universal necessities that are essential for well-being and psychological growth regardless of gender, social class and cultural context (Deci \& Ryan, 2008; Vansteenkiste \& Ryan, 2013). Empirical SDT studies provide evidence of relationships between basic psychological needs satisfaction and positive outcomes (well-being, autonomous motivation and other academic outcomes) in educational context for various age groups (Haerens, Aelterman, Vansteenkiste, Soenens, \& Van Petegem, 2015; Kanat-Maymon, Benjamin, Stavsky, Shoshani, \& Roth, 2015; Koka \& Hagger, 2010; Milyavskaya, Philippe, \& Koestner, 2013; Rutten, Boen, \& Seghers, 2012). While SDT postulates that these needs are distinct and hold unique influences on autonomous motivation (Gagné \& Deci, 2005; Ryan \& Deci, 2000b; Vansteenkiste, Niemiec, \& Soenens, 2010), some empirical studies in educational settings overlook this statement by defining need satisfaction as unidimensional construct (Haerens et al., 2015; Kanat-Maymon et al., 2015; Katz, Kaplan, \& Gueta, 2009; Mouratidis, Barkoukis, \& Tsorbatzoudis, 2015). Moreover, such conceptualization of need satisfaction does not take into account possible interactions between all three needs. Thus, the main aim of the present study was to examine the different interactive effects of the student perceptions of satisfaction of the basic psychological needs in school context - autonomy, competence, and relatedness - on student-reported academic motivation.

Previous research has suggested three hypotheses of interaction among the basic psychological needs: additive, synergistic, and balance hypotheses (Dysvik, Kuvaas, \& Gagné, 2013). The additive hypothesis has been most commonly studied, while the synergistic and balance hypotheses have been studied to a lesser extent. To our knowledge, the last hypothesis - balance - has not been examined in educational domain. Accordingly, in this study we investigated interactions between the three psychological needs and their influence on autonomous motivation in educational settings in the light of additive, synergistic, and balance hypotheses. Our empirical investigation of these hypotheses is expected to be among the first attempts to shed light on the effects of combinations of students' needs satisfaction in predicting their autonomous motivation. 


\section{Autonomous Motivation and Basic Psychological Needs}

In defining a person's motivational orientation toward various behaviors, SDT (Deci \& Ryan, 2000; Ryan \& Deci, 2000a) distinguishes between three categories of motivation based on their position on a continuum ranging from high to low degrees of self-determination (extent to which a behavior is freely chosen by individuals): autonomous motivation, controlled motivation, and amotivation. Autonomous motivation comprises both intrinsic motivation and the types of extrinsic motivation in which people find personal meaning and significance of activity (Deci \& Ryan, 2008). When students are autonomously motivated, they experience volition, psychological freedom and greater ownership of the behavior. Autonomous motivation stands for the highest quality of academic motivation, that is, it predicts such important academic outcomes as effective performance, creative problem solving, and deep or conceptual learning (Ryan \& Deci, 2000a; Vallerand, 2000). Controlled motivation, in contrast, consists of both external regulation, in which one's behavior is a function of external rewards or punishments, and introjected regulation, in which the regulation of action has been partially internalized and driven by internal pressure to gain pride or avoid guilt and shame (Deci \& Ryan, 2008). When students are controlled, they behave with the experience of pressure and coercion to think, feel, or behave in particular ways. Both autonomous and controlled motivation provide behavior with energy and direction, and they are contrasted with amotivation that reflects the lack of intention to act (Deci \& Ryan, 2008).

Individual's motivational orientation may be shaped by environmental context. SDT claims that to move across motivation continuum towards more autonomously motivated behaviors, three psychological needs (i.e., need for autonomy, need for competence, and need for relatedness) should be satisfied (Deci \& Ryan, 2000, 2011). Noticeably, in SDT, the level of need satisfaction is more important for high quality motivation and well-being than extent to which individual or cultural context values or desires these needs (Chen et al., 2015; Deci \& Ryan, 2000). The need for autonomy reflects the striving to experience free will and to be the initiator of one's action (Deci \& Ryan, 2000; Deci \& Vansteenkiste, 2004). When the need for autonomy is satisfied at school, students feel they are involved in decision-making about the learning process, and can choose what and how to learn. They regulate their behavior and efforts without external control and pressure (Connell \& Wellborn, 1991; Deci, Vallerand, Pelletier, \& Ryan, 1991). The need for competence implies that individuals seek to be effective and experience confidence in performing necessary actions and achieving desired outcomes (Deci \& Ryan, 2000; Deci \& Vansteenkiste, 2004). Satisfaction of this need leads students to perceive themselves as capable to adopt required learning strategies, complete academic tasks, and maintain persistency (Connell \& Wellborn, 1991; Elliot, McGregor, \& Thrash, 2002; Park, Holloway, Arendtsz, Bempechat, \& Li, 2012). The desire to establish and maintain close, secure and caring relationships, and feel connected to others is characteristic of the need for relatedness (Deci \& 
Ryan, 2000; Deci \& Vansteenkiste, 2004). Satisfaction of the need for relatedness gives perception of emotional closeness with significant people at school while engaging in learning activities (Koka \& Hagger, 2010; Park et al., 2012). Overall, the student who has a sense of choice and mastery in the learning process, feels closely related with other individuals at school, and is expected to have a higher level of autonomous motivation to learn.

\section{Combined Effects of the Satisfaction of Basic Psychological Needs: Additive, Synergistic, and Balance Hypotheses}

According to SDT, all three needs are important and contribute uniquely to autonomous motivation (Deci \& Ryan, 2000; Gagné \& Deci, 2005; Vansteenkiste et al., 2010). Moreover, satisfaction of each psychological need is not independent of or in conflict with satisfaction of other needs; rather, they are interrelated and complement each other (Ryan \& Deci, 2000b; Vallerand, 2000). Since some empirical studies in educational domain conceptualized need satisfaction as unidimensional construct, they confirmed the association between satisfaction of needs and autonomous motivation (Haerens et al., 2015; Kanat-Maymon et al., 2015; Katz et al., 2009; Mouratidis et al., 2015; Sebire, Jago, Fox, Edwards, \& Thompson, 2013), but not the unique contribution of each need satisfaction to autonomous motivation. Researchers combined scores of autonomy, competence and relatedness to get one indicator of need satisfaction, therefore they established the effect of all needs satisfaction but defied the importance of each need. Other scholars used separate indicators for each need and evaluated the main effects of needs satisfaction on autonomous motivation (Amoura et al., 2015; Joesaar, Hein, \& Hagger, 2011; Koka \& Hagger, 2010; Rutten et al., 2012) and other academic outcomes such as emotional engagement (Park et al., 2012) and school adjustment (Ratelle \& Duchesne, 2014). However, examining only the main effects does not take into account theoretical statements about possible interactions between all needs. Thus, instead of using an average score, we evaluated the satisfaction of each need separately, and in addition to main effects, we analyzed the combined effects.

Three hypotheses have been tested so far to validate SDT theoretical statement about interrelatedness of the basic psychological needs: additive, synergistic and balance. According to additive hypothesis, each of three needs uniquely predicts autonomous motivation, regardless of the level of satisfaction of other needs. It is possible that the satisfaction of one need can be sufficient for a person to be autonomously motivated. This hypothesis has been tested the most (Dysvik et al., 2013). In contrast, the synergistic hypothesis states that even though each need is necessary to increase autonomous motivation, none of them is sufficient to cause this effect on its own. In other words, all three needs must be satisfied for autonomous motivation to emerge. The balance hypothesis proposes that all three needs must be satisfied to the same extent in addition to a total amount of need satisfaction for a 
person to be autonomously motivated. This means that individuals who experience balanced need satisfaction would be more autonomously motivated than those with the equal general level of need satisfaction but with greater variability.

Additive hypothesis has been confirmed in different cultures, variety of domains as well as across the lifespan, and in cross-sectional and experimental designs (e.g., Park et al., 2012; Sheldon \& Filak, 2008; Sheldon \& Niemiec, 2006; Véronneau, Koestner, \& Abela, 2005). The results of the experimental study by Sheldon and Filak (2008) supported the additive hypothesis over the synergistic. This study showed that all three needs had main effects on intrinsic motivation, but no interactive effects. Sheldon and Niemiec (2006) proposed and supported balance hypothesis. They conducted 4 studies to examine whether the balance in the satisfaction of needs predicts several indicators of well-being above and beyond each need satisfaction level. Balance effect emerged consistently across concurrent, prospective, daily-diary and observed study designs. In recent years, the balance hypothesis was also tested and supported in sports-based research on autonomous motivation and well-being (Mack et al., 2011; Mouratidis et al., 2015). Dysvik et al. (2013) conducted two studies in occupational settings where they aimed to test all three hypotheses for intrinsic motivation. They partially supported both additive and synergistic hypotheses. Additive hypothesis was supported with regards to autonomy and relatedness, but no relationship was found between intrinsic motivation and competence satisfaction. Synergistic hypothesis was tested examining the three-way and two-way interactions between the needs. The results did not support three-way interaction, only two-way interaction between autonomy and competence was found in both studies. Dysvik et al. (2013) did not confirm the balance hypothesis. To summarize, synergistic and balance hypotheses have been studied much less than additive. Therefore, the way in which the needs interact with regard to autonomous motivation, still remains unclear. Given that interaction effects can be sample- and domain-specific, it is important to test the same hypotheses in educational settings where mastery is an essential feature.

\section{Aims of the Present Study}

In the present study we focused on the unique relationships between the satisfaction of the three psychological needs at school and autonomous motivation for learning in late adolescence. Three hypotheses were tested: (1) satisfaction of each need would independently predict autonomous motivation (additive hypothesis); (2) interaction between needs satisfaction would account for variance in autonomous motivation beyond the main effects of the three needs (synergistic hypothesis), and (3) balance in needs satisfaction would predict autonomous motivation above and beyond each need satisfaction and their interaction (balance hypothesis). We expected that both the main effects and combinations of needs satisfaction would be important for academic autonomous motivation.

In examining this set of hypotheses, we controlled for the role of gender and age. This was done because previous research had shown that (a) girls were more 
autonomously motivated than boys (e.g., Ratelle, Guay, Vallerand, Larose, \& Senécal, 2007) and that (b) there is a decrease in autonomous motivation with age (e.g., Gillet, Vallerand, \& Lafrenière, 2012).

\section{Method}

\section{Participants and Procedure}

The data was drawn from the first available wave of ongoing longitudinal research “Towards effective teaching: Dynamic interaction between teachers' instructional behavior and students' basic psychological needs satisfaction (DoIT)". Participants were students in grades 9-11 from seven schools in four districts of Lithuania, representing all regions of the country. Out of the expected sample (number of students in the school lists reported by schools officials) consisting of 781 students, 682 students participated in the first assessment (participation rate 87.3\%). For the current study, only the participants who filled in at least $65 \%$ of all relevant measures were included in the analyses. Thus, the sample size for this study was 679 students $(49.3 \%$ girls). The age ranged from 14 to 18 years with a mean age of 16.16 years $(\mathrm{SD}=.91)$. Most participants were Lithuanian (94.5\%), while others included participants from Polish (2.8\%), Russian (1.3\%), and other language-minority families (1.3\%) while 1.3\% of them did not specify their ethnicity. Parents received a letter with the information about the aim of the research via electronic day-book. In case they objected to the participation of their child in the study, parents were asked to contact the leader of the research team (i.e., a passive informed consent was obtained). Participation in the study was voluntary and participants were assured of confidentiality. Students who agreed to participate in the study completed the questionnaires during regular class time under the supervision of the researcher. Teachers were asked to leave the room while the questionnaire was being filled out.

\section{Measures}

The questionnaires for present study were translated from English into Lithuanian, the participants' language of instruction at school, using the guidelines of the International Test Commission (Hambleton, 1994).

\section{Basic Psychological Need Satisfaction at School}

Basic psychological need satisfaction at school was assessed with the Basic Psychological Need Satisfaction and Frustration Scale (BPNSFS, Chen et al., 2015). We used the version of this scale that was modified for children by Van der KaapDeeder et al. (2015). The scale consists of 24 items that measure the needs satisfaction (4 items per need) as well as the frustration ( 4 items per need). For the present study the stem "At school..." was added before items. All items were rated on a 5-point scale (1- completely untrue, 5- completely true). To obtain a satisfaction score for each of the three needs, 8 items were averaged (frustration items were reverse coded). Sample 
items are: "I feel free to choose which activities I do" (autonomy satisfaction), "I can do things well" (competence satisfaction), and "The people that I like, also like me" (relatedness satisfaction). Cronbach's alpha values were .76, .75, .82 for autonomy satisfaction, competence satisfaction, and relatedness satisfaction, respectively.

Chen et al. (2015) provided evidence for the factorial validity in four samples of different cultural background. We conducted CFA to examine the internal structure of this questionnaire in the current sample. Confirmatory factor analysis indicated that a three factor model fitted the data adequately: $x^{2}(237)=556.479, \mathrm{p}<.0001$, $\mathrm{CFI}=.90, \mathrm{RMSEA}=.044,[.040 ; .049], \mathrm{SRMR}=.05$. All indicator loadings were above .55 ( $\mathrm{p}<.001)$, except one item on autonomy satisfaction scale, which was $.40(\mathrm{p}<.001)$, and the one on competence satisfaction scale, which was .39 ( $\mathrm{p}<.001)$.

Following Sheldon and Niemiec (2006) procedure, balance in need satisfaction was computed finding the difference between each pair of needs and then summing the absolute values of the three difference scores. The resulting scores were then subtracted from the highest observed score of 7 . This helped to create a variable in which higher values represented more balance in satisfaction of the three needs.

\section{Autonomous Academic Motivation}

The Academic Motivation Scale (AMS; Vallerand, Blais, Brière, \& Pelletier, 1989) was used to assess students' motivational orientations. The scale consists of seven subscales with 4 items each. Three subscales measure intrinsic motivation: to know, for accomplishment, and stimulation. Three subscales measure extrinsic motivation: identified regulation, introjected regulation, and external regulation. The seventh subscale measures amotivation. All items represented students' answers to the question "Why do you go to school?", and they were rated on a scale from 1 (does not correspond at all) to 7 (corresponds exactly). Sample items are: "Because I experience pleasure and satisfaction while learning new things" (intrinsic motivation to know); "For the pleasure I experience while surpassing myself in my studies" (intrinsic motivation towards accomplishments); "Because I really like going to school" (intrinsic motivation to experience stimulation); "Because I think that a high-school education will help me prepare better for the career I have chosen" (identified regulation); "To prove to myself that I am capable of completing my high-school degree" (introjected regulation); "In order to obtain a more prestigious job later on" (external regulation) and "I don't know; I can't understand what I am doing in school" (amotivation). Cronbach's alpha values ranged from .73 (intrinsic motivation for stimulation) to .87 (amotivation).

The seven subscales' scores were combined into a Relative Autonomy Index (RAI, Grolnick \& Ryan, 1987) to get a single measure of the level of autonomous motivation. Such scores are regularly used by SDT researchers (e.g., Amoura et al., 2015; Guay, Ratelle, Roy, \& Litalien, 2010) to assess individuals' level of autonomous motivation relative to their level of controlled motivation and amotivation. RAI was calculated by assigning weights to subscales representing their amount of self-determination. 
Subscales that represent autonomous motivation were weighted positively, and subscales that represent controlled motivation and amotivation were weighted negatively. Thus, a weight of +2 was assigned to intrinsic motivation score (obtained by averaging the scores of three intrinsic motivation subscales), a weight of +1 was assigned to identified regulation score, a weight of -1 was assigned to introjected and external regulations, a weight of -2 was assigned to amotivation. The following formula was used: $2 \times$ intrinsic motivation + identified regulation - (introjected regulation + external regulation) $/ 2-2 \times$ amotivation. Higher scores on RAI reflect higher levels of autonomous motivation.

AMS has been found to be a reliable and valid measure in different samples and across various cultures (Alivernini \& Lucidi, 2008; Barkoukis, Tsorbatzoudis, Grouios, \& Sideridis, 2008; Cokley, Bernard, Cunningham, \& Motoike, 2001; Guay, Morin, Litalien, Valois, \& Vallerand, 2015; Vallerand et al., 1993; Zhang, Li, Li, Li, \& Zhang, 2015 CFA was conducted to assess internal structure of this questionnaire in the current sample. A five-factor model in which subscales of intrinsic motivation comprised a higher order factor was tested. Fit indices were adequate: $x^{2}(335)=$ 914.411, $p<.0001 \mathrm{CFI}=.92$, RMSEA $=.05,[.047 ; .054]$, SRMR $=.058$. All indicator loadings were above $.55(p<.001)$, except one item on an external regulation subscale, which was $.36(p<.001)$.

\section{Results \\ Descriptives}

The means, standard deviations, correlations of measures of autonomy, competence, and relatedness need satisfaction, a balance score, and a measure of autonomous motivation are presented in Table 1. As expected, the three measures of need satisfaction and the balanced score were positively related with autonomous motivation.

Table 1

Means, standard deviations, and correlations of the study variables

\begin{tabular}{llcccccccc}
\hline & Variable & $\mathrm{M}$ & $\mathrm{SD}$ & 1 & 2 & 3 & 4 & 5 & 6 \\
\hline 1 & Gender & 1.51 & .05 & - & & & & & \\
& (girls = 1, boys = 2) & & & & & & & & \\
2 & Age & 16.16 & .91 & .01 & - & & & & \\
3 & Need for autonomy (Aut) & 2.92 & .61 & .02 & -.03 & - & & & \\
4 & Need for competence (Com) & 3.41 & .57 & $.14^{* * *}$ & -.05 & $.42^{* * *}$ & - & & \\
5 & Need for relatedness (Rel) & 3.99 & .56 & $-.13^{* *}$ & -.01 & $.22^{* * *}$ & $.39^{* * *}$ & - & \\
6 & Balance & 4.55 & 1.24 & $.12^{* *}$ & -.04 & $.66^{* * *}$ & $.11^{* *}$ & $-.44^{* * *}$ & - \\
7 & Autonomous motivation & 4.03 & 4.90 & $-.23^{* * *}$ & $-.08^{*}$ & $.45^{* * *}$ & $.30^{* * *}$ & $.32^{* * *}$ & $.20^{* * *}$ \\
${ }^{*} p<.05,{ }^{* *} p<.01,{ }^{* * *} p<.001$ & & & & & & & &
\end{tabular}

\section{Hierarchical Regression Analysis}

To test our study hypotheses, we performed a four-step hierarchical multiple regression analysis with autonomous motivation scores as the dependent variable. 
Gender and age were entered in Step 1 as control variables. In Step 2, the variables of autonomy, competence and relatedness satisfaction were entered, thus, testing for additive hypothesis. Two-way interactions and a three-way interaction of need satisfaction were entered as predictors in Step 3 to test synergistic hypothesis. Interaction variables were created by centering means of the predictors (to avoid multicollinearity) and multiplying them with each other. Finally, to test the balance hypothesis, the balance variable was entered in Step 4.

As composite variables of interaction and balance were used together with their constituent variables as predictors in Step 4, multicollinearity diagnostics was performed prior to analysis. Tolerance values and Variance inflation indexes (VIF's) were used as multicollinearity statistics. The lowest tolerance value was .18, which is above the threshold value of .10 (Kline, 2011). Two VIFs were between 4 and 6, but they were considerably smaller than 10 , which is a value of extreme multicollinearity (Kline, 2011). Thus, it can be concluded that regression coefficient estimates can be interpreted in a reliable manner.

The results of the hierarchical regression analysis are presented in Table 2. The results showed that after controlling the variables of gender and age all three needs had independent positive effect and accounted for $31.1 \%$ of the variation in autonomous motivation in Step 2. In Step 3, three-way interaction was not significant, and only one two-way interaction between competence and autonomy was significant at $p=.051$. This interaction significantly added to the prediction of autonomous motivation beyond the main effects of needs satisfaction, that is $\Delta \mathrm{R}^{2}=.013, p<.05$. In Step 4 , a balance score was a significant positive predictor of autonomous motivation above and beyond the level of each need satisfaction, and the interaction between competence and autonomy $\left(\Delta \mathrm{R}^{2}=.009, p<.01\right)$. Together, all three needs satisfaction, interaction between competence and autonomy, and balance in need satisfaction accounted for $33.3 \%$ of the variance in autonomous motivation. Significant main effects of autonomy, competence, and relatedness need satisfaction on autonomous motivation provide support for additive hypothesis. Synergistic hypothesis was partially supported because synergistic relationships were found between competence and autonomy, but not between other two pairs of needs, and all three needs combined. The balance contributed significantly to autonomous motivation beyond the level of needs satisfaction, thus supporting the third hypothesis.

To interpret our only significant interaction, we examined association between competence and autonomous motivation at low (one standard deviation below mean using standardized scores) and high (one standard deviation above the mean) levels of autonomy using simple slope analysis (Cohen, J., Cohen, P., West, \& Aiken, 2003). First, we calculated the region of significance (RoS), that is, the specific values of the moderator (i.e., autonomy) for which the relation between independent variable (i.e., competence) and dependent value (i.e., autonomous motivation) becomes significant. 
The results showed that only with the low values of autonomy the relation between competence and autonomous motivation becomes statistically significant (i.e., outside the region $.14-7.99$, calculated at $p=.05$ ) The actual minimum and maximum values for autonomy were 1.92 and 1.96, respectively, indicating that none of the participants could score higher than the higher boundary of RoS (7.99). Secondly, we calculated the simple slopes for low $(-1 S D)$ and high $(+1 S D)$ values of the moderator (autonomy) (see Figure 1). The results showed that the simple slope of the low value $(-1 S D)$ of the moderator is significant $(\beta=1.49$, S.E. $=.41, t=3.69, p<.001)$. However, the simple slope of the $+1 S D$ of the moderator (autonomy) fails to reach statistical significance $(\beta=.19$, S.E. $=.48, t=.39, p=.70)$. Finally, we calculated the region of significance (RoS) for independent variable (feeling of competence) in which the moderator (autonomy) has a significant effect on dependent variable (autonomous motivation). As depicted in Figure 1, the results showed that both slopes of autonomy ( $-1 S D$ of the moderator value and $+1 S D$ of the moderator value) were significantly different from each other when the independent variable (feeling of competence) was outside the region 1.13-28.93 (outside grey area in Figure 1). In sum, the slopes displayed in Figure 1 suggest that high satisfaction of need for autonomy led to autonomous motivation regardless of satisfaction of need for competence. However, competence was related to autonomous motivation only when the need for autonomy was low. That is, in a group of low autonomy, the greater the feeling of competence the student experienced, the higher autonomous motivation she or he had.

Table 2

Hierarchical regression analysis predicting autonomous motivation by satisfaction of needs for autonomy, competence, and relatedness

\begin{tabular}{|c|c|c|c|c|}
\hline & \multicolumn{3}{|c|}{ Autonomous motivation } & \multirow[b]{2}{*}{ Step 4} \\
\hline & Step 1 & Step 2 & Step 3 & \\
\hline Gender (girls $=1$, boys $=2$ ) & $-.23^{* * *}$ & $-.23^{* * *}$ & $-.24^{* * *}$ & $-.24^{* * *}$ \\
\hline Age & $-.08^{*}$ & -.06 & -.06 & -.06 \\
\hline Need for autonomy (Aut) & & $.37^{* * *}$ & $.42^{* * *}$ & $.24^{* * *}$ \\
\hline Need for competence (Com) & & $.11^{* *}$ & $.10^{* *}$ & $.097^{*}$ \\
\hline Need for relatedness (Rel) & & $.17^{* * *}$ & $.18^{* * *}$ & $.31^{* * *}$ \\
\hline Com $\times$ Aut & & & $-.08^{\dagger}$ & $-.09 *$ \\
\hline Com $\times$ Rel & & & -.05 & -.05 \\
\hline Aut $\times$ Rel & & & -.01 & -.01 \\
\hline Aut $\times$ Com $\times$ Rel & & & -.06 & -.05 \\
\hline Balance & & & & $.22^{* *}$ \\
\hline $\mathrm{R}^{2}$ & .06 & .31 & .33 & .33 \\
\hline$\Delta \mathrm{R}^{2}$ & & $.252^{* * *}$ & $.013^{*}$ & $.009^{* *}$ \\
\hline $\mathrm{F}$ & $21.09^{* * *}$ & $60.79^{* * *}$ & $35.72^{* * *}$ & $33.37^{* * *}$ \\
\hline
\end{tabular}

Note. Standardized regression coefficients are shown. $+p<.055,{ }^{*} p<.05,{ }^{* *} p<.01,{ }^{* * *} p<.001$ 


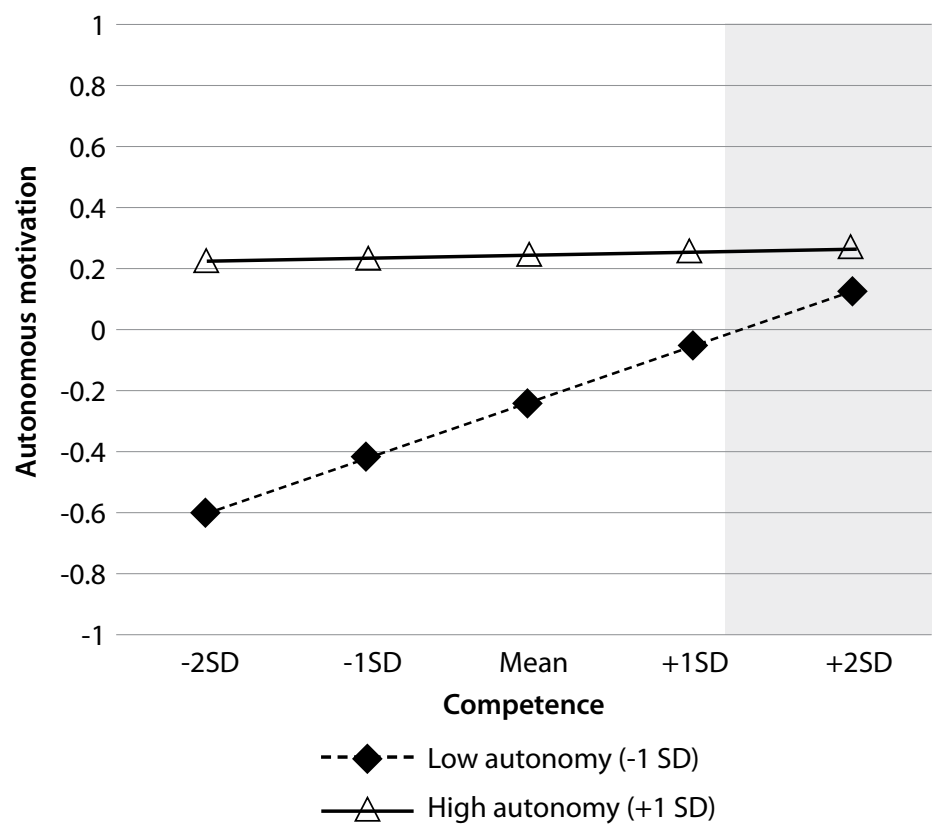

Figure 1. The moderating role of feeling autonomous on the association between feeling competent and autonomous motivation. In the white area, the lines of -1 SD and +1 SD of the moderator value (satisfaction of the need of autonomy) are significantly different from each other; in the grey area, the -1 SD and +1 SD of the moderator value are not significantly different from each other

\section{Discussion}

The purpose of this study was to examine the satisfaction of basic psychological needs for autonomy, competence and relatedness as a mechanism to promote academic autonomous motivation for high school students. According to SDT, each need holds a unique value for emergence of autonomous motivation and subsequent well-being, therefore the satisfaction of all three needs is essential. It is equally important to understand the manner in which needs can possibly interact. SDT researchers tested the additive, synergistic and balanced hypotheses of needs interaction. However, the results are still inconclusive to provide consistent understanding of unique explanatory power of each need in predicting autonomous motivation. This study contributes to the existing body of research by enhancing the understanding, and these are conditions under which feelings of competence, autonomy and relatedness impact autonomous motivation in educational settings. Overall, as expected, the results confirmed that both the main effects and combinations of needs satisfaction would be important for autonomous academic motivation.

We first tested additive hypothesis that the satisfaction of the needs for autonomy, competence and relatedness has an independent effect on autonomous motivation. We confirmed this hypothesis with regards to all three needs. Satisfaction of each of the needs at school leads to students' experience of volition and self-determination 
in learning activities. Our findings are consistent with the basic assumption of SDT about the importance and uniqueness of three needs in facilitating inherent activity and promoting optimal motivation (Ryan \& Deci, 2000). Additive hypothesis gained most empirical support in predicting various positive outcomes, such as various aspects of well-being, and motivation (e.g., Sheldon \& Filak, 2008; Sheldon \& Niemiec, 2006; Véronneau et al., 2005). Noticeably, our results are in contrast to some of the other studies that tested different interrelations between needs but failed to find the main effects of each need satisfaction. For example, Dysvik et al. (2013) did not find the unique contribution of competence to intrinsic work motivation, and Mack et al. (2011) did not find the main effect of relatedness on well-being after adding balance in a sample of young adult volleyball players. The results of the current study showed that the main effects of three needs remained significant in all steps of the analysis. This can be due to the fact that some previous research examined work motivation (Dysvik et al., 2013) or performance in sports (Mack et al., 2011). However, the beneficial role of needs satisfaction has gained support in educational domain (Milyavskaya et al., 2009; Ratelle \& Duchesne, 2014).

The second hypothesis about synergistic relations stated that interaction between need satisfaction would account for variance in autonomous motivation beyond the main effects of three needs. We aimed to test full synergistic effect by examining threeway need interaction and partial synergistic effect by analyzing interaction in pairs of needs. Only two-way interaction between competence and autonomy had significant effect on autonomous motivation thus partially supporting synergistic hypothesis. These results indicate that high satisfaction of need for autonomy led to autonomous motivation regardless the satisfaction of need for competence. However, competence was positively related to autonomous motivation only when need for autonomy was low. The results point to the importance of competence in circumstances when school context does not support need for autonomy. Dysvik et al. (2013) also found significant effects of interaction between competence and autonomy on intrinsic work motivation. However, the pattern of synergistic effect between competence and autonomy was different. In contrast to our results, competence was positively related to intrinsic motivation when autonomy was high. Dysvik et al. (2013) explain their results by pointing out the differences in motivational processes during the acquisition of mastery and after having established mastery. At work, people can be characterized by established mastery, while adolescents are in the process of acquisition of mastery. This can explain different synergistic effects in work and educational domains. In addition, Dysvik et al. (2013) found the synergistic effects between autonomy and relatedness, and relatedness and competence. However, these results were not replicated in their second study. In contrast, other studies using experimental design failed to find any support for the synergistic hypothesis for intrinsic motivation of college students (Sheldon \& Filak, 2008). Therefore, the results of the existing studies about synergistic needs interaction are inconsistent, and sound 
conclusions cannot be made. However, although our results provide some support for the synergistic hypothesis (combined effect of satisfying need for autonomy and need for competence on students' autonomous motivation), this type of interaction could be the focus of future research about basic psychological needs satisfaction in relation to optimal functioning.

The third hypothesis stated that a balance in need satisfaction would predict autonomous motivation above and beyond each need satisfaction and their interaction. The results confirmed that the balance in need satisfaction, in addition to additive and synergistic effects, is important for autonomous motivation. This suggests that students who experience equivalent need satisfaction at school would have higher autonomous academic motivation than those with the same total amount of need satisfaction but with greater variability. Similar importance of balance with regards to well-being was reported in previous research. The role of balance was supported using various methodologies in Sheldon and Niemiec's (2006) studies. Mack et al. (2011) found relationship between balance and one aspect of well-being, vitality. Our findings also correspond to other studies that related balance with autonomous or intrinsic motivation in sports (Mouratidis et al., 2015) and work domain (Dysvik et al., 2013). In the latter domain, however, the effect of balance was significant only in one of two studies. In line with Sheldon and Niemiec's (2006) reasoning, the role of balance for positive outcomes can be explained by a tendency of individuals to reduce inconsistencies in various areas of their life. It is possible that disbalance in need satisfaction leads to tension and higher levels of stress, which in turn directs attention and energy towards the least satisfied need. Individuals become more sensitive to environmental cues that suggest opportunities for need satisfaction (Vansteenkiste et al., 2012). The energy is distributed unevenly as individuals organize their experience to reduce disbalance; consequently, this prevents them from thriving. Since our results and results elsewhere point to the importance of balance, future research is needed to provide explanations for possible mechanisms of balance effect. This finding implies that teachers should try to support equally the satisfaction of all three students' basic psychological needs in educational process. All three needs can be supported at the same level when teachers provide choices, explain the relevance of learning activities and assignments, accept negative criticism from students, provide clear guidelines and positive feedback, express warmth, interest, and positive feelings towards students.

The present study has limitations that restrict the generalizability of our results. First, we used cross-sectional data to test our hypotheses. However, analyzing previous studies one can notice that the importance of basic psychological needs for autonomous motivation is evident regardless of the design of the study. Still, future studies should focus on longitudinal data and apply more conservative test where, for example, previous level of the constructs is controlled for.

Secondly, students' self-reports have been used to test our hypotheses. Thus, it is possible that self-report bias could have inflated the associations. The results could 
also have suffered from social desirability. However, students' reports can be justified because motivation and need satisfaction are subjective in nature, thus, individuals are the best evaluators of their own autonomous motivation and their own subjective feelings of satisfaction of their basic needs for autonomy, competence, and relatedness. Nonetheless, multiple informants would provide a more comprehensive perspective on needs' satisfying learning experience.

\section{Conclusions}

The present study is one of the first empirical studies conducted in educational settings, which examined the interaction between the needs for autonomy, competence, and relatedness and their influence on children's autonomous motivation. On the sample of high school students additive effects were demonstrated: all three needs had significant and unique effects on autonomous motivation. The balance in need satisfaction and interrelation between autonomy and competence had additional independent effects. To sum up, the current study established additive effects and contributed to the existing knowledge about the synergistic and balance effects of needs satisfaction on autonomous motivation. The impact of balance in needs satisfaction on autonomous motivation is better supported by evidence than effects of synergistic interaction. While the synergistic effects are least demonstrated, the existing small body of work suggests that relations of needs satisfactions with autonomous motivation might be different in different groups of individuals.

Overall, the results raise awareness about the importance of students' needs satisfaction at school to achieve high quality motivation and optimal functioning. It can be recommended to organize educational process in a way that helps students to satisfy all three basic psychological needs with low variability among them. Moreover, in case autonomy support is less possible, efforts should be directed towards strengthening feelings of competence.

\section{References}

Alivernini, F., \& Lucidi, F. (2008). The academic motivation scale (AMS): Factorial structure, invariance, and validity in the Italian context. TPM - Testing, Psychometrics, Methodology in Applied Psychology, 15(4), 211-220.

Amoura, C., Berjot, S., Gillet, N., Caruana, S., Cohen, J., \& Finez, L. (2015). Autonomysupportive and controlling styles of teaching: Opposite or distinct teaching styles? Swiss Journal of Psychology, 74(3), 141-158. https://doi.org/10.1024/1421-0185/a000156

Barkoukis, V., Tsorbatzoudis, H., Grouios, G., \& Sideridis, G. (2008). The assessment of intrinsic and extrinsic motivation and amotivation: Validity and reliability of the Greek version of the Academic Motivation Scale. Assessment in Education: Principles, Policy \& Practice, 15(1), 39-55. https://doi.org/10.1080/09695940701876128

Chen, B., Vansteenkiste, M., Beyers, W., Boone, L., Deci, E. L., Van der Kaap-Deeder, J., ... Verstuyf, J. (2015). Basic psychological need satisfaction, need frustration, and need 
strength across four cultures. Motivation and Emotion, 39(2), 216-236. https://doi. org/10.1007/s11031-014-9450-1

Cohen, J., Cohen, P., West, S. G., \& Aiken, L. S. (2003). Applied multiple regression/correlation analysis for the behavioral sciences (3rd ed.). London: Lawrence Erlbaum Associates.

Cokley, K. O., Bernard, N., Cunningham, D., \& Motoike, J. (2001). A Psychometric investigation of the Academic Motivation Scale using a United States Sample. Measurement and Evaluation in Counseling and Development, 34(2), 109-119.

Connell, J. P., \& Wellborn, J. G. (1991). Competence, autonomy and relatedness: A motivational analysis of self-system processes. In M. Gunnar, \& L. A. Sroufe (Eds.), The Minnesota Symposium on Child Psychology: Self processes in development (Vol. 22, pp. 4377). Hillsdale, NJ: Erlbaum.

Deci, E. L., \& Ryan, R. M. (2000). The "What" and "Why" of goal pursuits: Human needs and the self-determination of behavior. Psychological Inquiry, 11(4), 227-268. https://doi. org/10.1207/S15327965PLI1104 01

Deci, E. L., \& Ryan, R. M. (2008). Self-determination theory: A macrotheory of human motivation, development, and health. Canadian Psychology/Psychologie Canadienne, 49(3), 182-185. https://doi.org/10.1037/a0012801

Deci, E. L., \& Ryan, R. M. (2011). Levels of analysis, regnant causes of behavior and wellbeing: The role of psychological needs. Psychological Inquiry, 22, 17-22. https://doi.org/1 $\underline{0.1080 / 1047840 X .2011 .545978}$

Deci, E. L., Vallerand, R., Pelletier, L., \& Ryan, R. (1991). Motivation and education: The self-determination perspective. Educational Psychologist, 26(3), 325-346. https://doi. org/10.1207/s15326985ep2603\&4 6

Deci, E. L., \& Vansteenkiste, M. (2004). Self-determination theory and basic need satisfaction: Understanding human development in positive psychology. Ricerche Di Psicologia, 27, 17-34.

Dysvik, A., Kuvaas, B., \& Gagné, M. (2013). An investigation of the unique, synergistic and balanced relationships between basic psychological needs and intrinsic motivation. Journal of Applied Social Psychology, 43(5), 1050-1064. https://doi.org/10.1111/jasp.12068

Elliot, A. J., McGregor, H. A., \& Thrash, T. M. (2002). The need for competence. In Deci E. L., \& Ryan R. M. (Eds.), Handbook of self-determination research (pp. 361-387). Rochester, New York: University of Rochester Press.

Gagné, M., \& Deci, E. L. (2005). Self-determination theory and work motivation. Journal of Organizational Behavior, 26, 331-362. https://doi.org/10.1002/job.322

Gillet, N., Vallerand, R. J., \& Lafrenière, M. A. K. (2012). Intrinsic and extrinsic school motivation as a function of age: The mediating role of autonomy support. Social Psychology of Education, 15(1), 77-95. https://doi.org/10.1007/s11218-011-9170-2

Grolnick, W. S., \& Ryan, R. M. (1987). Autonomy in children's learning: An experimental and individual difference investigation. Journal of Personality and Social Psychology, 52(5), 890-898. https://doi.org/10.1037/0022-3514.52.5.890

Guay, F., Morin, A. J. S., Litalien, D., Valois, P., \& Vallerand, R. J. (2015). Application of exploratory structural equation modeling to evaluate the academic motivation scale. The Journal of Experimental Education, 83(1), 51-82. https://doi.org/10.1080/00220973 .2013 .876231 
Guay, F., Ratelle, C. F., Roy, A., \& Litalien, D. (2010). Academic self-concept, autonomous academic motivation, and academic achievement: Mediating and additive effects. Learning and Individual Differences, 20(6), 644-653. https://doi.org/10.1016/j.lindif.2010.08.001

Haerens, L., Aelterman, N., Vansteenkiste, M., Soenens, B., \& Van Petegem, S. (2015). Do perceived autonomy-supportive and controlling teaching relate to physical education students' motivational experiences through unique pathways? Distinguishing between the bright and dark side of motivation. Psychology of Sport and Exercise, 16, 26-36. https:// doi.org/10.1016/j.psychsport.2014.08.013

Hambleton, R. K. (1994). Guidelines for adapting educational and psychological tests: A progress report. European Journal of Psychological Assessment, 10, 229-244.

Joesaar, H., Hein, V., \& Hagger, M. S. (2011). Peer influence on young athletes' need satisfaction, intrinsic motivation and persistence in sport: A 12-month prospective study. Psychology of Sport and Exercise, 12(5), 500-508. https://doi.org/10.1016/j. psychsport.2011.04.005

Kanat-Maymon, Y., Benjamin, M., Stavsky, A., Shoshani, A., \& Roth, G. (2015). The role of basic need fulfillment in academic dishonesty: A self-determination theory perspective. Contemporary Educational Psychology, 43, 1-9. https://doi.org/10.1016/j. cedpsych.2015.08.002

Katz, I., Kaplan, A., \& Gueta, G. (2009). Students' needs, teachers' support, and motivation for doing homework: A cross-sectional Study. The Journal of Experimental Education, 78(2), 246-267. https://doi.org/10.1080/00220970903292868

Kline, R. B. (2011). Principles and practice of structural equation modeling (3rd ed.). New York: Guilford Press.

Koka, A., \& Hagger, M. S. (2010). Perceived teaching behaviors and self-determined determination theory. Research Quarterly for Exercise and Sport, 81(1), 74-86. https://doi. org/10.1080/02701367.2010.10599630

Lepper, M. R., Corpus, J. H., \& Iyengar, S. S. (2005). Intrinsic and extrinsic motivational orientations in the classroom: Age differences and academic correlates. Journal of Educational Psychology, 97(2), 184-196. https://doi.org/10.1037/0022-0663.97.2.184

Mack, D. E., Wilson, P. M., Oster, K. G., Kowalski, K. C., Crocker, P. R. E., \& Sylvester, B. D. (2011). Well-being in volleyball players: Examining the contributions of independent and balanced psychological need satisfaction. Psychology of Sport and Exercise, 12(5), 533-539. https://doi.org/10.1016/j.psychsport.2011.05.006

Milyavskaya, M., Gingras, I., Mageau, G. A., Koestner, R., Gagnon, H., Fang, J., ... Fourier, J. (2009). Balance Across Contexts: Importance of Balanced Need Satisfaction Across Various Life Domains. Personality and Social Psychology Bulletin, 35(8), 1031-1045. https:// doi.org/10.1177/0146167209337036

Milyavskaya, M., Philippe, F. L., \& Koestner, R. (2013). Psychological need satisfaction across levels of experience: Their organization and contribution to general well-being. Journal of Research in Personality, 47(1), 41-51. https://doi.org/10.1016/j.jrp.2012.10.013

Mouratidis, A., Barkoukis, V., \& Tsorbatzoudis, C. (2015). The relation between balanced need satisfaction and adolescents' motivation in physical education. European Physical Education Review, 21(4), 421-431. https://doi.org/10.1177/1356336X15577222

Park, S., Holloway, S. D., Arendtsz, A., Bempechat, J., \& Li, J. (2012). What makes students engaged in learning? A Time-use study of within- and between-individual predictors of 
emotional engagement in low-performing high schools. Journal of Youth and Adolescence, 41(3), 390-401. https://doi.org/10.1007/s10964-011-9738-3

Ratelle, C. F., \& Duchesne, S. (2014). Trajectories of psychological need satisfaction from early to late adolescence as a predictor of adjustment in school. Contemporary Educational Psychology, 39, 388-400. https://doi.org/10.1016/j.cedpsych.2014.09.003

Ratelle, C. F., Guay, F., Vallerand, R. J., Larose, S., \& Senécal, C. (2007). Autonomous, controlled, and amotivated types of academic motivation: A person-oriented analysis. Journal of Educational Psychology, 99(4), 734-746. https://doi.org/10.1037/0022-0663.99.4.734

Rutten, C., Boen, F., \& Seghers, J. (2012). How school social and physical environments relate to autonomous motivation in physical education: The mediating role of need satisfaction. Journal of Teaching in Physical Education, 31, 216-230. https://doi.org/10.1123/itpe.31.3.216

Ryan, R. M., \& Deci, E. L. (2000a). Self-determination theory and the facilitatiton of intrinsic motivation, social development, and well-being. American Psychological Association, 55(1), 68-78.

Ryan, R. M., \& Deci, E. L. (2000b). The darker and brighter sides of human existence: Basic psychological needs as a unifying concept. Psychological Inquiry, 11(4), 319-338. https:// doi.org/10.1207/S15327965PLI1104 03

Sebire, S. J., Jago, R., Fox, K. R., Edwards, M. J., \& Thompson, J. L. (2013). Testing a selfdetermination theory model of children's physical activity motivation: A cross-sectional study. International Journal of Behavioral Nutrition and Physical Activity, 10, 1-9. https:// doi.org/10.1186/1479-5868-10-111

Sheldon, K. M., \& Filak, V. (2008). Manipulating autonomy, competence, and relatedness support in a game-learning context: New evidence that all three needs matter. The British Journal of Social Psychology/the British Psychological Society, 47(2), 267-283. https://doi. org/10.1348/014466607X238797

Sheldon, K. M., \& Niemiec, C. P. (2006). It's not just the amount that counts: Balanced need satisfaction also affects well-being. Journal of Personality and Social Psychology, 91(2), 331-341. https://doi.org/10.1037/0022-3514.91.2.331

Skinner, E. A., Kindermann, T. A., Connell, J. P., \& Wellborn, J. G. (2009). Engagement and disaffection as an organizational construct in the dynamics of motivational development. In K. Wentzel, \& A. Wigfield (Eds.), Handbook of motivation in school (pp. 223-245). Mahwah, NJ: Erlbaum

Vallerand, R. (2000). Deci and Ryan's self-determination theory: A view from the hierarchical model of intrinsic and extrinsic motivation. Psychological Inquiry, 11(4), 312-318.

Vallerand, R. J., Blais, M. R., Brière, N. M., \& Pelletier, L. G. (1989). Construction et validation de l'Échelle de Motivation en Éducation (EME). Revue canadienne des sciences du comportement, 21, 323-349. https://doi.org/10.1037/h0079855

Vallerand, R. J., Pelletier, L. G., Blais, M. R., Briere, N. M., Senecal, C., \& Vallieres, E. F. (1993). On the assessment of intrinsic, extrinsic, and amotivation in education: Evidence on the concurrent and construct validity of the academic motivation scale. Educational and Psychological Measurement, 53(1), 159-172. https://doi.org/10.1177/0013164493053001018

Van der Kaap-Deeder, J., Vansteenkiste, M., Soenens, B., Loeys, T., Mabbe, E., \& Gargurevich, R. (2015). Autonomy-supportive parenting and autonomy-supportive sibling interactions: The role of mothers' and siblings' psychological need satisfaction. Personality and Social Psychology Bulletin, 41(11), 1590-1604. https://doi.org/10.1177/0146167215602225 
Vansteenkiste, M., Niemiec, C. P., \& Soenens, B. (2010). The development of the five minitheories of self-determination theory: An historical overview, emerging trends, and future directions. Advances in Motivation and Achievement Series, 16, Part A, 105-166. https://doi. org/10.1108/S0749-7423(2010)000016A007

Vansteenkiste, M., \& Ryan, R. M. (2013). On psychological growth and vulnerability: Basic psychological need satisfaction and need frustration as a unifying principle. Journal of Psychotherapy Integration, 23(3), 263-280. https://doi.org/10.1037/a0032359

Vansteenkiste, M., Sierens, E., Goossens, L., Soenens, B., Dochy, F., Mouratidis, A., ... Beyers, W. (2012). Identifying configurations of perceived teacher autonomy support and structure: Associations with self-regulated learning, motivation and problem behavior. Learning and Instruction, 22(6), 431-439. https://doi.org/10.1016/j.learninstruc.2012.04.002

Véronneau, M., Koestner, R. F., \& Abela, J. R. Z. (2005). Intrinsic Need Satisfaction and Well-Being in Children and Adolescents: An Application of the Self-Determination Theory. Journal of Social and Clinical Psychology, 24(2), 280-292. https://doi.org/10.1521/ jscp.24.2.280.62277

Zhang, B., Li, Y. M., Li, J., Li, Y., \& Zhang, H. (2015). The revision and validation of the Academic motivation scale in China. Journal of Psychoeducational Assessment, 34(1), 15-27. https://doi.org/10.1177/0734282915575909

\section{Saulè Raižienè}

Mykolas Romeris University, Institute of Psychology

Ateities str. 20, LT-08303 Vilnius, Lithuania

s.raiziene@mruni.eu

\section{Ingrida Gabrialavičiūtè}

Mykolas Romeris University, Institute of Psychology

Ateities str. 20, LT-08303 Vilnius, Lithuania

ingrida gab@mruni.eu

\section{Renata Garckija}

Mykolas Romeris University, Institute of Psychology

Ateities str. 20, LT-08303 Vilnius, Lithuania

r.garckija@mruni.eu

\section{Gintautas Silinskas}

University of Jyväskylä, Department of Psychology

P.O. Box 35, 40014 Jyväskylä, Finland

gintautas.silinskas@jyu.fi 


\section{Zadovoljavanje osnovnih psiholoških potreba i autonomna motivacija u kontekstu škole: testiranje aditivne, sinergističke i hipoteze ravnoteže}

\section{Sažetak}

U ovom je istraživanju ispitivan utjecaju triju osnovnih psiholoških potreba na autonomnu motivaciju u obrazovnom okruženju s obzirom na aditivnu, sinergističku $i$ hipotezu ravnoteže. Sudionici u istraživanju bili su srednjoškolci, ukupno njih $679\left(M_{d o b}=16,16 ; 49,3 \%\right.$ djevojaka). Rezultati su išli u prilog aditivnoj hipotezi: sve tri potrebe imaju jedinstven utjecaj na autonomnu motivaciju. Sinergistička hipoteza samo je dijelom potvrdena: jedna dvosmjerna interakcija izmedu autonomije $i$ kompetentnosti imala je utjecaj na autonomnu motivaciju. Visok stupanj zadovoljavanja potrebe za autonomijom vodi autonomnoj motivaciji bez obzira na to je li zadovoljena potreba za kompetentnošću. Međutim, kompetentnost je u pozitivnoj vezi s autonomnom motivacijom samo onda kada je potreba za autonomijom bila mala. Hipoteza ravnoteže je također potvrđena: ravnoteža zadovoljavanja potreba, uz aditivan i sinergistički, ima također važan utjecaj.

Ključne riječi: obrazovno okruženje; potreba za autonomijom; potreba za kompetentnošć; potreba za povezivanjem; teorija samoodređenja.

\section{Uvod}

Škola je kontekst u kojem pojedinac koji je u razvoju provodi znatan dio vremena. Obrazovni kontekst omogućava pristup informacijama, mogućnosti za druženje i razvoj osobnih kvaliteta. Stoga je školski uspjeh put prema napretku u životu odraslog čovjeka. Aktivno sudjelovanje učenika i u akademskim i u društvenim školskim aktivnostima neophodno je kako bi se iskoristile prilike koje se učenicima pružaju u obrazovnom okruženju. Međutim, entuzijazam učenika za učenje tijekom godina školovanja opada, pogotovo u prijelaznim razdobljima (Lepper, Corpus, i Iyengar, 2005; Skinner, Kindermann, Connell, i Wellborn, 2009. Stoga je, posebno tijekom posljednjih godina formalnog obrazovanja, važno preispitati izvore visoke akademske motivacije. 
Tijekom nekoliko prošlih desetljeća teorija samoodređenja (Deci i Ryan, 2000) omogućila je koristan okvir za objašnjenje procesa koji se nalaze u pozadini motivacije učenika. Prema teoriji samoodređenja, kada učenici iskuse zadovoljavanje urođenih psiholoških potreba za autonomijom, kompetentnošću i povezanošću, osjećaju autonomnu motivaciju (tj. sudjeluju u aktivnosti radi same aktivnosti, zato što im je ugodna ili smislena). Osnovne psihološke potrebe definiraju se kao univerzalne potrebe koje su neophodne za skladnost i psihološki rast, bez obzira na spol, društveni položaj i kulturni kontekst (Deci i Ryan, 2008; Vansteenkiste i Ryan, 2013). Empirijska istraživanja o teoriji samoodređenja pružaju dokaze o vezi između zadovoljavanja osnovnih psiholoških potreba i pozitivnih ishoda (skladnost, autonomna motivacija i drugi akademski ishodi) u obrazovnom kontekstu, za različite dobne skupine (Haerens, Aelterman, Vansteenkiste, Soenens, i Van Petegem, 2015; Kanat-Maymon, Benjamin, Stavsky, Shoshani, i Roth, 2015; Koka i Hagger, 2010; Milyavskaya, Philippe, i Koestner, 2013; Rutten, Boen, i Seghers, 2012). Dok su prema teoriji samoodređenja te potrebe jasne i imaju jedinstven utjecaj na autonomnu motivaciju (Gagné i Deci, 2005; Ryan i Deci, 2000b; Vansteenkiste, Niemiec, i Soenens, 2010), neka empirijska istraživanja provedena u obrazovnom okruženju previdjela su tu postavku kada su definirala zadovoljavanje potrebe kao jednodimenzionalni konstrukt (Haerens i sur., 2015; Kanat-Maymon i sur., 2015; Katz, Kaplan i Gueta, 2009; Mouratidis, Barkoukis i Tsorbatzoudis, 2015). Štoviše, takva konceptualizacija zadovoljavanja potreba ne uzima u obzir moguće interakcije između svih triju potreba. Stoga je glavni cilj ovog istraživanja ispitati različite interaktivne utjecaje koje način na koji učenici shvaćaju zadovoljavanje osnovnih psiholoških potreba u kontekstu škole - autonomiju, kompetentnost i povezanost - ima na akademsku motivaciju koju su učenici naveli.

Prijašnja su istraživanja predložila tri hipoteze o interakciji između osnovnih psiholoških potreba: aditivnu, sinergističku i hipotezu ravnoteže (Dysvik, Kuvaas, i Gagné, 2013). Aditivna hipoteza je najčešće proučavana, a istraživanja su se u manjoj mjeri bavila sinergističkom hipotezom i hipotezom ravnoteže. Koliko je nama poznato, posljednja hipoteza, hipoteza ravnoteže, nije do sada istražena u obrazovnom okruženju. Stoga su u ovom istraživanju ispitivane interakcije između triju psiholoških potreba i njihov utjecaj na autonomnu motivaciju u obrazovnom okruženju s obzirom na aditivnu, sinergističku i hipotezu ravnoteže. Očekuje se da će naše empirijsko ispitivanje tih hipoteza biti među prvim pokušajima rasvjetljavanja utjecaja kombinacije zadovoljavanja učeničkih potreba na predviđanje njihove autonomne motivacije.

\section{Autonomna motivacija i osnovne psihološke potrebe}

Pri definiranju motivacijske orijentacije neke osobe prema različitim vrstama ponašanja, teorija samoodređenja (Deci i Ryan, 2000, 2000a) razlikuje tri kategorije motivacije s obzirom na njihov položaj u kontinuumu, od visokih do niskih stupnjeva samoodređenja (mjere u kojoj pojedinci slobodno biraju ponašanje): autonomnu 
motivaciju, kontroliranu motivaciju i amotivaciju. Autonomna motivacija sastoji se i od intrinzične motivacije i od tipova ekstrinzične motivacije u kojima ljudi pronalaze osobno značenje i važnost aktivnosti (Deci i Ryan, 2008). Kada su učenici autonomno motivirani, osjećaju voljnost, psihološku slobodu i imaju osjećaj veće kontrole i posjedovanja određenog tipa ponašanja. Autonomna motivacija ujedno je i najkvalitetnija akademska motivacija, jer predviđa važne akademske ishode poput učinkovitog obavljanja zadataka, kreativnog rješavanja problema i dubokog ili konceptualnog učenja (Ryan i Deci, 2000a; Vallerand, 2000). Za razliku od autonomne motivacije, kontrolirana se motivacija sastoji i od eksterne regulacije, u kojoj je neka vrsta ponašanja uvjetovana eksternom nagradom ili kaznom, i od introjecirane regulacije, u kojoj je regulacija neke radnje djelomično internalizirana i potaknuta unutarnjim pritiskom za osjećaj ponosa ili za izbjegavanje krivnje ili stida (Deci i Ryan, 2008). Kada su učenici kontrolirani, osjećaju pritisak i prisilu da razmišljaju, osjećaju i ponašaju se na određen način. I autonomna i kontrolirana motivacija daju ponašanju energiju i smjer te su suprotnost amotivaciji, koja odražava nepostojanje namjere da se djeluje (Deci i Ryan, 2008).

Motivacijsku orijentaciju pojedinca može oblikovati okolina. Prema teoriji samoodređenja, ako pojedinac treba prijeći kroz motivacijski kontinuum prema ponašanju koje je autonomno motivirano, moraju biti zadovoljene tri motivacijske potrebe (potreba za autonomijom, potreba za kompetentnošću i potreba za povezanošću) (Deci i Ryan, 2000, 2011). Očito je da je u teoriji samoodređenja stupanj zadovoljavanja potreba važniji za kvalitetnu motivaciju i skladnost nego mjera u kojoj pojedinac ili kulturni kontekst cijeni ili želi te potrebe (Chen i sur., 2015; Deci i Ryan, 2000). Potreba za autonomijom reflektira tendenciju prema iskustvu slobodne volje i želje da pojedinac sam inicira svoje djelovanje (Deci i Ryan, 2000, Deci i Vanseenkiste, 2004). Kada se u školi zadovolji potreba za autonomijom, učenici osjećaju da su uključeni u proces donošenja odluka o procesu učenja i da mogu odabrati što i kako učiti. Reguliraju svoje ponašanje i ulažu trud bez vanjske kontrole i pritiska (Connell i Wellborn, 1991; Deci, Vallerand, Pelletier, i Ryan, 1991). Potreba za kompetentnošću implicira da pojedinci žele biti učinkoviti i iskusiti samopouzdanje pri izvršavanju potrebnih zadataka te postići željene ciljeve (Deci i Ryan, 2000; Deci i Vansteenkiste, 2004). Zadovoljavanje te potrebe vodi učenike tome da sebe smatraju sposobnima usvojiti tražene strategije učenja, izvršiti akademske zadatke te biti ustrajni (Connell i Wellborn, 1991; Elliot, McGregor, i Thrash, 2002; Park, Holloway, Arendtsz, Bempechat, i Li, 2012). Potreba za uspostavljanjem i održavanjem bliskih, sigurnih i brižnih veza, i za osjećajem povezanosti s drugima, karakteristika je potrebe za povezanošću (Deci i Ryan, 2000; Deci i Vansteenkiste, 2004). Zadovoljavanje potrebe za povezanošću daje osjećaj emocionalne blizine s važnim ljudima u školi tijekom sudjelovanja u aktivnostima učenja (Koka i Hagger, 2010; Park i sur., 2012). Općenito, učenik koji ima osjećaj mogućnosti izbora i napretka u procesu učenja osjeća se blisko povezan s drugim pojedincima u školi i očekuje se da će imati viši stupanj autonomne motivacije za učenje. 


\section{Kombinirani utjecaji zadovoljavanja osnovnih psiholoških potreba: aditivna, sinergistička i hipoteza ravnoteže}

Prema teoriji samoodređenja, sve tri potrebe su važne i daju jedinstven doprinos autonomnoj motivaciji (Deci i Ryan, 2000; Gagné i Deci, 2005; Vansteenkiste i sur., 2010). Štoviše, zadovoljavanje svake psihološke potrebe neovisno je i nije suprotno zadovoljavanju drugih potreba; štoviše, one su međusobno isprepletene i nadopunjuju se (Ryan i Deci, 2000b; Vallerand, 2000). Budući da su neka empirijska istraživanja u obrazovnom području definirala zadovoljavanje potreba kao jednodimenzionalni konstrukt, potvrdila su vezu između zadovoljavanja potreba i autonomne motivacije (Haerens i sur., 2015; Kanat-Maymon i sur., 2015; Katz i sur., 2009; Mouratidis i sur., 2015; Sebire, Jago, Fox, Edwards, i Thompson, 2013), ali ne i jedinstven doprinos zadovoljavanja svake potrebe autonomnoj motivaciji. Istraživači su kombinirali rezultate autonomije, kompetentnosti i povezanosti kako bi dobili pokazatelj zadovoljavanja potreba. Tako su definirali utjecaj zadovoljavanja svih potreba, ali su zanemarili važnost svake pojedinačne potrebe. Drugi su se, pak, koristili zasebnim pokazateljima za svaku potrebu i procijenili su glavne utjecaje zadovoljavanja potreba na autonomnu motivaciju (Amoura i sur., 2015; Joesaar, Hein, i Hagger, 2011; Koka i Hagger, 2010; Rutten i sur., 2012) i druge akademske ishode poput emocionalne angažiranosti (Park i sur., 2012) i prilagodbe školi (Ratelle i Duchesne, 2014). Međutim, ispitivanje samo glavnih utjecaja ne uzima u obzir teorijske tvrdnje o mogućim interakcijama između svih potreba. Stoga, umjesto korištenja prosječnog rezultata, procijenili smo zadovoljavanje svake potrebe zasebno, te smo uz glavne utjecaje analizirali i kombinirane utjecaje.

Do sada su testirane tri hipoteze kako bi se provjerila teorijska postavka teorije samoodređenja o međusobnoj povezanosti osnovnih psiholoških potreba: aditivna, sinergistička i hipoteza ravnoteže. Prema aditivnoj hipotezi, svaka od tri potrebe na jedinstven način predviđa autonomnu motivaciju, bez obzira na stupanj zadovoljavanja ostalih potreba. Moguće je da zadovoljavanje jedne potrebe može biti dovoljno da bi se osoba osjećala autonomno motivirana. Ta hipoteza bila je najčešće testirana (Dysvik i sur., 2013). Suprotno tome, sinergistička hipoteza navodi da, iako je svaka potreba neophodna kako bi se povećala autonomna motivacija, nijedna od njih pojedinačno nije dovoljna kako bi sama povećala autonomnu motivaciju. Drugim riječima, sve tri potrebe moraju se zadovoljiti kako bi se pojavila autonomna motivacija. Hipoteza ravnoteže predlaže da sve tri potrebe moraju biti zadovoljene u jednakoj mjeri, uz ukupno zadovoljavanje svih potreba, kako bi se osoba osjećala autonomno motivirana. To znači da bi pojedinci koji su iskusili uravnoteženo zadovoljavanje potreba bili više autonomno motivirani od onih s jednakim općim stupnjem zadovoljavanja potreba, ali s većom raznolikošću.

Aditivna hipoteza potvrđena je u različitim kulturama, raznolikim područjima i različitim dobnim skupinama, kao i u presječnim i eksperimentalnim istraživanjima (npr. Park i sur., 2012; Sheldon i Filak, 2008; Sheldon i Niemiec, 2006; Véronneau, 
Koestner, i Abela, 2005). Rezultati eksperimentalnog istraživanja koje su proveli Sheldon i Filak (2008) potvrdili su aditivnu hipotezu prije nego sinergističku. Ovo je istraživanje pokazalo da sve tri potrebe imaju značajan utjecaj na intrinzičnu motivaciju, ali nemaju interaktivni utjecaj. Sheldon i Niemiec (2006) predložili su i potvrdili hipotezu ravnoteže. Proveli su 4 istraživanja kako bi ispitali može li se ravnotežom u zadovoljavanju potreba predvidjeti nekoliko pokazatelja skladnosti izvan zadovoljavanja svake potrebe. Utjecaj ravnoteže sustavno se susreće u aktualnim i budućim istraživanjima, kao i u onima koja se koriste dnevnikom i opažanjima. U posljednjih nekoliko godina hipoteza ravnoteže je također testirana i potvrđena u istraživanjima u području sporta o autonomnoj motivaciji i skladnosti (Mack i sur., 2011; Mouratidis i sur., 2015). Dysvik i suradnici (2013) proveli su dva istraživanja u radnom okruženju kojima su namjeravali testirati sve tri hipoteze, ali u području intrinzične motivacije. Djelomično su potvrdili i aditivnu i sinergističku hipotezu. Aditivna hipoteza potvrđena je s obzirom na autonomiju i povezanost, no nije utvrđena veza između intrinzične motivacije i zadovoljavanja potrebe za kompetentnošću. Sinergistička hipoteza testirana je ispitivanjem trosmjernih i dvosmjernih interakcija između potreba. Rezultati nisu potvrdili trosmjerne interakcije, nego samo dvosmjernu interakciju između autonomije i kompetentnosti, i to u oba istraživanja. Dysvik i suradnici (2013) nisu potvrdili hipotezu ravnoteže. Da zaključimo, sinergistička hipoteza i hipoteza ravnoteže proučavane su manje nego aditivna. Stoga je još uvijek nejasno u kakvom su međusobnom odnosu potrebe s autonomnom motivacijom. Kako utjecaj interakcije može biti vezan uz uzorak i domenu, važno je testirati iste hipoteze u obrazovnom okruženju, gdje je uspjeh bitna karakteristika.

\section{Ciljevi istraživanja}

U ovom istraživanju usredotočili smo se na jedinstvenu vezu između zadovoljavanja triju psiholoških potreba u školi i autonomne motivacije za učenje u kasnoj adolescenciji. Testirane su tri hipoteze: (1) zadovoljavanje svake potrebe moglo bi neovisno predvidjeti autonomnu motivaciju (aditivna hipoteza); (2) interakcija između zadovoljavanja potreba mogla bi objasniti razliku u autonomnoj motivaciji, izvan okvira glavnog učinka triju potreba (sinergistička hipoteza) i (3) ravnoteža (balans) u zadovoljavanju potreba mogla bi predvidjeti autonomnu motivaciju izvan zadovoljavanja svake potrebe pojedinačno, kao i njihovu interakciju (hipoteza ravnoteže). Očekivali smo da će i glavni utjecaji i kombinacija zadovoljavanja potreba biti važni za autonomnu akademsku motivaciju.

Ispitujući tu skupinu hipoteza, razmotrili smo i ulogu spola i dobi. To smo učinili zbog toga što su prijašnja istraživanja pokazala (a) da su djevojke bile u većoj mjeri autonomno motivirane nego dječaci (npr. Ratelle, Guay, Vallerand, Larose, i Senécal, 2007) i (b) da se u starijoj dobi može uočiti smanjenje autonomne motivacije (npr. Gillet, Vallerand, i Lafrenière, 2012). 


\section{Metoda}

\section{Sudionici i postupak}

Podatci su dobiveni iz prvog dostupnog vala longitudinalnog istraživanja koje je još u tijeku, „Prema učinkovitom poučavanju: dinamična interakcija između ponašanja nastavnika u nastavi i zadovoljavanja osnovnih psiholoških potreba učenika“. Sudionici su bili učenici koji su pohađali razrede od 9. do 11., iz sedam škola u četiri područja Litve, predstavljajući tako sve regije države. Od očekivanog uzorka (broja učenika na popisima koje su dostavile školske službe) koji se sastojao od 781 učenika, 682 učenika sudjelovala su u prvoj procjeni (stopa sudjelovanja $87,3 \%$ ). Za potrebne analize u ovom istraživanju odabrani su samo oni učenici koji su ispunili barem $65 \%$ svih važnih mjerenja. Tako je veličina uzorka u ovom istraživanju bila 679 učenika (49,3\% djevojaka). Njihova dob bila je između 14 i 18 godina, a srednja dob 16,16 godina $(S D=0,91)$. Većina ispitanika bili su Litvanci $(94,5 \%)$, a ostali su porijeklom i po etničkoj pripadnosti bili Poljaci $(2,8 \%)$, Rusi $(1,3 \%)$ i drugi $(1,3 \%)$, koji nisu naveli svoju etničku pripadnost. Roditelji su putem e-dnevnika dobili pismo s informacijama o cilju istraživanja. U slučaju da se nisu slagali sa sudjelovanjem svojeg djeteta $u$ istraživanju, trebali su kontaktirati voditelja istraživanja (tj. dobiven je pasivni informirani pristanak). Sudjelovanje u istraživanju bilo je dobrovoljno, a sudionicima je zajamčena povjerljivost podataka. Učenici koji su pristali sudjelovati u istraživanju popunili su upitnike tijekom redovne nastave pod nadzorom istraživača. Nastavnici su zamoljeni da napuste učionicu dok se upitnik popunjavao.

\section{Mjerenja}

Upitnik koji se koristio u ovom istraživanju preveden je s engleskog jezika na litvanski, jezik na kojem se izvodi nastava u školi koju pohađaju sudionici, koristeći se smjernicama Međunarodne komisije za testove (Hambleton, 1994).

\section{Zadovoljavanje osnovnih psiholoških potreba u školi}

Zadovoljavanje osnovnih psiholoških potreba u školi ispitano je s pomoću Skale o zadovoljavanju osnovnih psiholoških potreba i frustracije (BPNSFS, Chen i sur., 2015). Koristili smo se inačicom te skale koju su za potrebe djece modificirali Van der Kaap-Deeder i sur. (2015). Skala se sastoji od 24 tvrdnje kojima se mjeri zadovoljavanje potreba (4 tvrdnje za svaku potrebu) i frustracija (4 tvrdnje za svaku potrebu). U ovom istraživanju u svaku smo tvrdnju dodali isti početak „U školi...“. Ovo su neki primjeri tvrdnji: „Osjećam se slobodnim/om odabrati koje aktivnosti želim raditi“ (zadovoljavanje potrebe za autonomijom), „Mogu dobro odraditi zadatke“ (zadovoljavanje potrebe za kompetentnošću), „Ljudi koje volim također vole mene“ (zadovoljavanje potrebe za povezanošću). Vrijednosti Cronbachove alfe bile su pojedinačno $0,76,0,75$ i 0,82 za zadovoljavanje potrebe za autonomijom, zadovoljavanje potrebe za kompetentnošću i zadovoljavanje potrebe za povezanošću.

Chen i sur. (2015) naveli su dokaze za faktorsku valjanost kod četiri uzorka iz različite kulturne sredine. Proveli smo konfirmatornu faktorsku analizu kako bismo 
ispitali unutarnju strukturu ovog upitnika na trenutnom uzorku. Konfirmatorna faktorska analiza pokazala je da model od tri faktora u potpunosti odgovara podatcima: $x^{2}(237)=556.479, \mathrm{p}<0,0001, \mathrm{CFI}=0,90, \mathrm{RMSEA}=0,044,[0,040 ; 0,049], \mathrm{SRMR}=0,05$. Sva faktorska opterećenja bila su iznad $0,55(\mathrm{p}<0,001)$, osim jedne tvrdnje na skali zadovoljavanja potreba za autonomijom, čija je vrijednost bila $0,40(\mathrm{p}<0,001)$, kao i jedne tvrdnje na skali zadovoljavanja potreba za kompetentnošću, čija je vrijednost bila $0,39(\mathrm{p}<0,001)$.

Prema postupku koji su proveli Sheldon i Niemiec (2006), i u ovom je istraživanju ravnoteža u zadovoljavanju potreba izračunata tako što je najprije utvrđena razlika između svakog para potreba, a onda su zbrojene apsolutne vrijednosti triju rezultata razlika. Ti su rezultati onda oduzeti od najvećeg dobivenog rezultata koji je iznosio 7. To je pomoglo u izradi varijable u kojoj su veće vrijednosti predstavljale veću ravnotežu u zadovoljavanju triju potreba.

\section{Autonomna akademska motivacija}

Skala akademske motivacije (AMS; Vallerand, Blais, Brière i Pelletier, 1989) koristila se za procjenu motivacijske orijentacije učenika. Skala se sastoji od sedam subskala od kojih svaka ima 4 tvrdnje. Tri subskale mjere intrinzičnu motivaciju: znati, zbog postignuća i stimulacija. Tri subskale mjere ekstrinzičnu motivaciju: prepoznata regulacija, introjecirana regulacija i eksterna regulacija. Sedma subskala mjeri amotivaciju. Sve tvrdnje predstavljaju odgovore učenika na pitanje: „Zašto ideš u školu?", a bile su ocijenjene na skali od 1 (uopće ne odgovara) do 7 (odgovara potpuno). Primjeri tvrdnji su: „Zato što osjećam ugodu i zadovoljstvo dok učim nove stvari“ (intrinzična motivacija za znanjem); „Zbog ugode koju osjetim kada nadmašim samog sebe u učenju“ (intrinzična motivacija za postignućem); „Zato što zaista volim ići u školu“ (intrinzična motivacija za stimulacijom); „Zato što mislim da će me srednjoškolsko obrazovanje bolje pripremiti za karijeru koju sam odabrao“ (prepoznata regulacija); „, Da bih sam sebi dokazao da sam sposoban završiti srednjoškolsko obrazovanje“ (introjecirana regulacija); „Kako bih kasnije mogao dobiti što bolji posao“ (eksterna regulacija) i „Ne znam; ne mogu shvatiti što uopće radim u školi“ (amotivacija). Vrijednosti Cronbachove alfe bile su u rasponu od 0,73 (intrinzična motivacija za stimulacijom) do 0,87 (amotivacija).

Rezultati sedam subskala kombinirani su u Relativni indeks autonomije (RAI, Grolnick i Ryan, 1987) kako bi se dobila jedna mjera za stupanj autonomne motivacije. Takvim se rezultatima redovito koriste stručnjaci koji se bave istraživanjem teorije samoodređenja (npr. Amoura i sur., 2015; Guay, Ratelle, Roy i Litalien, 2010 ), kako bi procijenili stupanj autonomije pojedinaca relativan s obzirom na njihov stupanj kontrolirane motivacije i amotivacije. Relativni indeks autonomije izračunat je tako što je određena težina za subskale koja je predstavljala njihov stupanj samoodređenja. Subskale koje prikazuju autonomnu motivaciju dobile su pozitivnu težinu, a subskale koje predstavljaju kontroliranu motivaciju i amotivaciju dobile su negativnu težinu. 
Tako je težina od +2 pripisana rezultatu intrinzične motivacije (dobivenom s pomoću prosječnih rezultata triju subskala intrinzične motivacije), težina od +1 dodana je rezultatu prepoznate regulacije, težina od -1 pripisana je introjeciranoj i eksternoj regulaciji, težina od -2 pripisana je amotivaciji. Koristila se ova formula: $2 \mathrm{x}$ intrinzična motivacija + prepoznata regulacija - (introjecirana regulacija - eksterna regulacija)/2 $-2 \mathrm{x}$ amotivacija. Veći rezultati na Relativnom indeksu autonomije odražavaju veći stupanj autonomne motivacije.

Skala autonomne motivacije pokazala se pouzdanom i valjanom mjerom na uzorcima iz različitih kultura (Alivernini i Lucidi, 2008; Barkoukis, Tsorbatzoudis, Grouios, i Sideridis, 2008; Cokley, Bernard, Cunningham, i Motoike, 2001; Guay, Morin, Litalien, Valois, i Vallerand, 2015; Vallerand i sur., 1993; Zhang, Li, Li, Li, i Zhang, 2015). Konfirmatorna faktorska analiza provedena je kako bi se procijenila unutarnja struktura upitnika na aktualnom uzorku. Testiran je model od pet faktora u kojemu su subskale intrinzične motivacije sadržavale faktor višeg reda. Indeksi prikladnosti bili su odgovarajući: $x^{2}(335)=914.411, p<0,0001$ CFI $=0,92$, RMSEA $=0,05,[0,047 ; 0,054], \mathrm{SRMR}=0,058$. Sva faktorska opterećenja bila su iznad 0,55 $(\mathrm{p}<0,001)$, osim za jednu tvrdnju na subskali eksterne regulacije, gdje je faktorsko opterećenje bilo $0,36(\mathrm{p}<0,001)$.

\section{Rezultati}

\section{Opis}

Srednje vrijednosti, standardne devijacije, korelacije mjerenja za zadovoljavanje potreba za autonomijom, kompetentnošću i povezanošću, rezultat ravnoteže zadovoljavanja potreba, kao i mjerenje autonomne motivacije, prikazani su u Tablici 1. Kao što je i bilo očekivano, sva tri mjerenja zadovoljavanja potreba i uravnotežen rezultat pozitivno su povezani s autonomnom motivacijom.

\section{Tablica 1}

\section{Hijerarhijska regresijska analiza}

Kako bismo testirali naše hipoteze u ovom istraživanju, proveli smo višestruku hijerarhijsku regresijsku analizu u kojoj su zavisne varijable bili rezultati autonomne motivacije. Spol i dob uvedeni su u prvoj fazi kao kontrolne varijable. U drugoj fazi uvedene su varijable: zadovoljavanje potreba za autonomijom, kompetentnošću i povezanošću, pa se tako testirala aditivna hipoteza. Dvosmjerne interakcije i trosmjerna interakcija zadovoljavanja potreba uvedene su kao prediktori u trećoj fazi kako bi se testirala sinergistička hipoteza. Varijable interakcije izrađene su centriranjem srednjih vrijednosti prediktora (da bi se izbjegla multikolinearnost) koje su tada pomnožene jedna drugom. Na kraju, kako bi se testirala hipoteza ravnoteže, u četvrtoj je fazi uvedena varijabla ravnoteže.

Kako su se kompozitne varijable interakcije i ravnoteže zajedno koristile sa svojim konstitutivnim varijablama kao prediktorima u četvrtoj fazi, multikolinearna 
dijagnostika provedena je prije analize. Vrijednosti tolerancije i indeksi inflacije varijance (VIF) koristili su se kao multikolinearna statistika. Najniža vrijednost tolerancije bila je 0,18, što je iznad vrijednosti praga od 0,10 (Kline, 2011). Dvije vrijednosti indeksa inflacije varijance bile su između 4 i 6 , ali ipak znatno niže od 10 , što je vrijednost ekstremne multikolinearnosti (Kline, 2011). Stoga se može zaključiti da se procjena koeficijenta regresije može pouzdano interpretirati.

Rezultati hijerarhijske regresijske analize prikazani su u Tablici 2. Rezultati su pokazali da nakon kontroliranja varijabli spola i dobi sve tri potrebe imaju neovisan pozitivan utjecaj i da su odgovorne za $31,1 \%$ varijacije u autonomnoj motivaciji u drugoj fazi. U trećoj fazi trosmjerna interakcija nije bila značajna, a samo je jedna dvosmjerna interakcija između kompetentnosti i autonomije bila značajna, $\mathrm{s}$ vrijednošću $\mathrm{p}=0,051$. Ta je interakcija značajan dodatak predviđanju autonomne motivacije izvan glavnih učinaka zadovoljavanja potreba, tj. $\Delta R 2=0,013, p<0,05$. $U$ četvrtoj fazi rezultat ravnoteže značajan je pozitivan prediktor autonomne motivacije izvan stupnja zadovoljavanja svake pojedinačne potrebe, kao i interakcije između kompetentnosti i autonomije ( $\Delta \mathrm{R} 2=0,009, \mathrm{p}<0,01)$. Zadovoljavanje svih triju potreba, interakcija između kompetentnosti i autonomije i ravnoteža zadovoljavanja potreba, sve zajedno, odgovorne su za 33,3\% varijance u autonomnoj motivaciji. Značajni glavni utjecaji zadovoljavanja potreba za autonomijom, kompetentnošću i povezanošću kod autonomne motivacije idu u prilog aditivnoj hipotezi. Sinergistička hipoteza djelomično je potvrđena jer su sinergističke veze utvrđene između kompetentnosti i autonomije, ali nisu utvrđene između druga dva para potreba i između kombinacije svih triju potreba. Ravnoteža je značajno doprinijela autonomnoj motivaciji neovisno o stupnju zadovoljavanja potreba te je tako potvrdila treću hipotezu.

\section{Tablica 2}

Kako bismo interpretirali našu jedinu značajnu interakciju, ispitali smo vezu između kompetentnosti i autonomne motivacije na niskom (jedna standardna devijacija ispod srednje vrijednosti uz korištenje standardiziranih rezultata) i na visokom (jedna standardna devijacija iznad srednje vrijednosti) stupnju autonomije, primjenom jednostavne analize kosine podataka (Cohen, Cohen, West, i Aiken, 2003). Najprije smo izračunali područje važnosti (RoS), tj. specifične vrijednosti moderatora (autonomiju) za koju veza između nezavisne varijable (kompetentnosti) i zavisne varijable (autonomne motivacije) postaje značajna. Rezultati su pokazali da jedino $s$ nižim vrijednostima autonomije veza između kompetentnosti i autonomne motivacije postaje statistički značajna (tj. izvan područja $0,14-7,99$, izračunato $\mathrm{s}=0,05$ ). Stvarne minimalne i maksimalne vrijednosti za autonomiju bile su -1,92 i 1,96, za svaku posebno, što upućuje na činjenicu da nitko od sudionika nije mogao imati veći rezultat od više granice područja važnosti $(7,99)$. Zatim smo izračunali jednostavne kosine za niske (-1 $S D)$ i visoke (+1 $S D$ ) vrijednosti moderatora (autonomije) (vidi Prikaz 1). Rezultati su pokazali da je jednostavna kosina niske vrijednosti $(-1 S D)$ moderatora 
značajna $(\beta=1,49$, S.E. $=0,41, t=3,69, p<0,001)$. Međutim, jednostavna kosina +1 $S D$ moderatora (autonomije) nije dosegla razinu statističke značajnosti $(\beta=0,19$, S.E. $=0,48, t=0,39, p=0,70)$. Na kraju smo izračunali područje važnosti za nezavisnu varijablu (osjećaj kompetentnosti) u kojoj moderator (autonomija) ima značajan utjecaj na zavisnu varijablu (autonomnu motivaciju). Kako je opisano u Prikazu 1, rezultati su pokazali da su obje kosine autonomije (-1 $S D$ vrijednosti moderatora i +1 SD vrijednosti moderatora) značajno različite jedna od druge kada je nezavisna varijabla (osjećaj kompetentnosti) izvan područja 1,13-28,93 (izvan sivog područja na Prikazu 1). Dakle, kosine koje se mogu vidjeti na Prikazu 1 upućuju na to da visok stupanj zadovoljavanja potrebe za autonomijom vodi prema autonomnoj motivaciji bez obzira na zadovoljavanje potrebe za kompetentnošću. Međutim, kompetentnost je povezana s autonomnom motivacijom samo onda kada je potreba za autonomijom mala. To znači da je, u skupini niske autonomije, što je veći osjećaj kompetentnosti koju učenik osjeća, to veća i njegova autonomna motivacija.

\section{Rasprava}

Svrha ovog istraživanja bila je ispitati zadovoljavanje osnovnih psiholoških potreba za autonomijom, kompetentnošću i povezanošću kao mehanizama za povećanje autonomne akademske motivacije kod srednjoškolaca. Prema teoriji samoodređenja, svaka potreba ima jedinstvenu vrijednost za pojavu autonomne motivacije i za skladnost nakon toga. Dakle, zadovoljavanje svih triju potreba je neophodno. Jednako je važno razumjeti način na koji potrebe mogu međusobno djelovati. Stručnjaci koji se bavi istraživanjem teorije samoodređenja testirali su aditivnu, sinergističku i hipotezu ravnoteže kod interakcije potreba. Međutim, rezultati su još uvijek nejasni da bi mogli dovesti do dosljednog razumijevanja načina na koji svaka potreba utječe na predviđanje autonomne motivacije. Ovo istraživanje doprinos je postojećim istraživanjima tako što pomaže boljem razumijevanju uvjeta pod kojima osjećaji kompetentnosti, autonomije i povezanosti utječu na autonomnu motivaciju u obrazovnom okruženju. Kako se i moglo očekivati, rezultati su potvrdili da i glavni utjecaji i kombinacije zadovoljavanja potreba mogu biti važni za autonomnu akademsku motivaciju.

Najprije smo testirali aditivnu hipotezu da zadovoljavanje potreba za autonomijom, kompetentnošću i povezanošću ima nezavisan utjecaj na autonomnu motivaciju. Potvrdili smo tu hipotezu uzimajući u obzir sve tri potrebe. Zadovoljavanje svake od tih potreba u školi vodi prema učenikovoj voljnosti i samoodređenju u aktivnostima učenja. Naši su rezultati u skladu s osnovnom pretpostavkom teorije samoodređenja o važnosti i jedinstvenosti triju potreba u olakšavanju temeljnih aktivnosti i u promicanju optimalne motivacije (Ryan i Deci, 2000). Aditivna hipoteza bila je u najvećoj mjeri empirijski potvrđena u predviđanju različitih pozitivnih ishoda, poput različitih aspekata skladnosti i motivacije (npr. Sheldon i Filak, 2008; Sheldon i Niemiec, 2006; Véronneau i sur., 2005). Kako se može vidjeti, naši rezultati ne podudaraju se $\mathrm{s}$ rezultatima nekih drugih istraživanja u kojima su se testirale različite međusobne 
veze između potreba, ali u kojima nisu pronađeni glavni utjecaji zadovoljavanja svake potrebe. Na primjer, Dysvik i suradnici (2013) nisu uočili jedinstven utjecaj kompetentnosti na intrinzičnu motivaciju za poslom, a Mack i suradnici (2011) nisu uočili glavni utjecaj povezanosti na skladnost nakon dodavanja ravnoteže na uzorku mlađih odraslih odbojkaša. Rezultati ovog istraživanja pokazali su da su glavni utjecaji triju potreba ostali značajni u svim fazama analize. To se može pripisati činjenici da su neka prijašnja istraživanja ispitivala radnu motivaciju (Dysvik i sur., 2013) ili uspjeh u sportu (Mack i sur., 2011). Međutim, korisna uloga zadovoljavanja potreba dobila je podršku u obrazovnom području (Milyavskaya i sur., 2009; Ratelle i Duchesne, 2014).

Druga hipoteza o sinergističkim vezama tvrdi da je interakcija između zadovoljavanja potreba odgovorna za varijancu u autonomnoj motivaciji izvan glavnih utjecaja triju potreba. Namjera nam je bila testirati potpuni sinergistički utjecaj ispitivanjem trosmjerne interakcije potreba i djelomični sinergistički utjecaj analizom interakcije u parovima potreba. Samo je dvosmjerna interakcija između kompetentnosti i autonomije imala značajan utjecaj na autonomnu motivaciju te je tako djelomično potvrdila sinergističku hipotezu. Navedeni rezultati upućuju na to da visok stupanj zadovoljavanja potrebe za autonomijom vodi prema autonomnoj motivaciji bez obzira na zadovoljavanje potrebe za kompetentnošću. Međutim, kompetentnost je pozitivno povezana s autonomnom motivacijom samo onda kada je potreba za autonomijom mala. Rezultati upućuju na važnost kompetentnosti u uvjetima kada školski kontekst ne podržava potrebu za autonomijom. Dysvik i suradnici (2013) također su uočili značajan utjecaj interakcije između kompetentnosti i autonomije na intrinzičnu motivaciju za rad. Međutim, uzorak sinergističkog utjecaja između kompetentnosti i autonomije bio je drugačiji. Suprotno našim rezultatima, kompetentnost je bila u pozitivnoj vezi s intrinzičnom motivacijom kada je stupanj autonomije bio visok. Dysvik i suradnici (2013) objasnili su svoje rezultate tako što su ukazali na razlike u motivacijskim procesima tijekom stjecanja vještina i nakon usvajanja vještina. $\mathrm{Na}$ poslu se ljudi mogu opisati prema usvojenim vještinama, a adolescenti su u procesu usvajanja vještina. To može objasniti različite sinergističke utjecaje na poslu i u obrazovnom području. K tomu, Dysvik i suradnici (2013) su pronašli sinergističke utjecaje između autonomije i povezanosti te povezanosti i kompetentnosti. Međutim, ti rezultati nisu potvrđeni u njihovu drugom istraživanju. Za razliku od toga, druga istraživanja koja su se koristila eksperimentalnim dizajnom nisu uspjela potvrditi sinergističku hipotezu o intrinzičnoj motivaciji studenata na fakultetu (Sheldon i Filak, 2008). Stoga su rezultati postojećih istraživanja o interakciji sinergističkih potreba nedosljedni te se ne mogu donijeti trajni zaključci. Međutim, iako naši rezultati u nekoj mjeri idu u prilog sinergističkoj hipotezi (kombinirani utjecaj zadovoljavanja potrebe za autonomijom i potrebe za kompetentnošću na autonomnu motivaciju učenika), takva vrsta interakcije mogla bi biti u središtu budućih istraživanja o zadovoljavanju osnovnih psiholoških potreba u odnosu na optimalno funkcioniranje.

Treća je hipoteza navela da bi ravnoteža u zadovoljavanju potreba mogla predvidjeti autonomnu motivaciju iznad i izvan zadovoljavanja svake potrebe, kao i njihovu 
interakciju. Rezultati su potvrdili da je ravnoteža u zadovoljavanju potreba, uz aditivni i sinergistički utjecaj, važna za autonomnu motivaciju. To upućuje na činjenicu da bi učenici koji iskuse zadovoljavanje potreba u školi mogli imati veći stupanj autonomne akademske motivacije nego oni učenici koji iskuse isti stupanj zadovoljavanja potreba, ali uz veću varijabilnost. Slična važnost ravnoteže s obzirom na skladnost navedena je i u prijašnjim istraživanjima. Uloga ravnoteže potvrđena je primjenom različitih metoda u istraživanjima koja su proveli Sheldon i Niemec (2006). Mack i suradnici (2011) uočili su vezu između ravnoteže i jednog aspekta skladnosti - vitalnosti. Naši rezultati su također u skladu s istraživanjima u kojima se ravnoteža dovela u vezu s autonomnom ili intrinzičnom motivacijom u sportu (Mouratidis i sur., 2015) i radnom okruženju (Dysvik i sur., 2013). No, u ovom drugom području utjecaj ravnoteže bio je značajan samo u jednom od dva istraživanja. U skladu s mišljenjem Sheldona i Niemeca (2006), uloga ravnoteže u pozitivnom ishodu može se objasniti tendencijom pojedinaca da reduciraju nedosljednosti u različitim područjima svog života. Moguće je da neravnoteža u zadovoljavanju potreba vodi napetosti i većem stupnju stresa, što za posljedicu ima usmjeravanje pažnje i energije na najmanje zadovoljenu potrebu. Ljudi postaju manje osjetljivi na znakove koji ih mogu dovesti do mogućnosti za zadovoljavanje potrebe (Vansteenkiste i sur., 2012). Energija je neravnomjerno raspoređena jer ljudi organiziraju svoja iskustva tako da smanje neravnotežu, što ih koči u napretku. Kako naši rezultati, ali i rezultati drugih istraživanja, upućuju na važnost ravnoteže, potrebna su daljnja istraživanja kako bi se objasnili mogući mehanizmi utjecaja ravnoteže. Navedeno ukazuje na to da bi nastavnici trebali pokušati podjednako zadovoljiti sve tri osnovne psihološke potrebe učenika tijekom obrazovnog procesa. Sve tri potrebe mogu se jednako zadovoljiti kada nastavnici učenicima pruže izbor, objasne važnost aktivnosti učenja i zadataka, prihvate negativnu kritiku od učenika, daju jasne smjernice i pozitivnu povratnu informaciju, pruže toplinu, pokažu interes i pozitivne osjećaje prema učenicima.

Ovo istraživanje ima ograničenja koja onemogućuju generalizaciju rezultata. Kao prvo, koristili smo se presječnim podatcima kako bismo testirali svoje hipoteze. Međutim, analizom prijašnjih istraživanja može se primijetiti važnost osnovnih psiholoških potreba za autonomnom motivacijom bez obzira na dizajn istraživanja. Ipak, buduća bi se istraživanja trebala usredotočiti na longitudinalne podatke i primijeniti konvencionalnije testove kada se, npr., kontrolira prethodni stupanj konstrukata.

Kao drugo, samoizvješća učenika koristila su se za testiranje hipoteza. Dakle, moguće je da je pristranost u tim samoizvješćima naglasila veze. Rezultati su isto tako mogli biti pod utjecajem društvene poželjnosti. No, izvješća učenika mogu se opravdati jer su motivacija i zadovoljavanje potreba po svojoj prirodi subjektivni, pa ljudi najbolje mogu procijeniti svoju autonomnu motivaciju i svoj subjektivni osjećaj zadovoljavanja vlastitih osnovnih potreba za autonomijom, kompetentnošću i povezanošću. Svejedno, više različitih ispitanika moglo bi dati sveobuhvatniji uvid u iskustvo učenja u kojem se zadovoljavaju potrebe. 
Na kraju, kulturni kontekst i njegova razlikovna obilježja također trebaju biti uzeti u obzir. Litva je mala istočnoeuropska zemlja s malom populacijom. Međutim, teorija samoodređenja tvrdi da je zadovoljavanje potreba univerzalno i da ne ovisi o kulturi. Potrebno je provesti više istraživanja u različitim kulturnim kontekstima kako bi se procijenila mogućnost generaliziranja rezultata.

\section{Zaključci}

Ovo istraživanje jedno je od prvih empirijskih istraživanja provedenih u obrazovnom okruženju, a koje je ispitivalo interakciju između potreba za autonomijom, kompetentnošću i povezanošću, kao i njihov utjecaj na autonomnu motivaciju djece. Na uzorku koji se sastojao od srednjoškolske populacije demonstrirani su aditivni utjecaji: sve tri potrebe imale su značajan i jedinstven utjecaj na autonomnu motivaciju. Ravnoteža u zadovoljavanju potreba i međusobna veza između autonomije i kompetentnosti imala je dodatan neovisan utjecaj. Da sažmemo, ovo istraživanje utvrdilo je postojanje aditivnog utjecaja i doprinijelo je postojećem znanju o sinergističkom utjecaju i utjecaju ravnoteže pri zadovoljavanju potreba na autonomnu motivaciju. Utjecaj ravnoteže u zadovoljavanju potreba na autonomnu motivaciju bolje se može potvrditi dokazima nego utjecajem sinergističke interakcije. Dok se sinergistički utjecaji najmanje mogu prikazati, postojeći malen broj radova upućuje na to da veze između zadovoljavanja potreba i autonomne motivacije mogu biti različite u različitim skupinama ispitanika.

Općenito gledajući, rezultati podižu svijest o važnosti zadovoljavanja potreba učenika u školi kako bi postigli veći stupanj kvalitetne motivacije i kako bi mogli funkcionirati na najbolji mogući način. Preporuka je organizirati nastavni proces tako da se učenicima pomogne u zadovoljavanju svih triju osnovnih psiholoških potreba s niskom varijabilnošću među njima. Štoviše, u slučaju da je teže dati potporu autonomiji, treba uložiti napore za jačanje osjećaja kompetentnosti. 